\title{
3 What Arab Women Say about Love
}

If a suitor asks, "Khaira, will you love me?"

“Macache!” (no), answers the houri.

Did she know it before birth? Be that as it may, it seems that the Arab woman has always known that to love is to suffer! But although she fears love, she ardently wishes to be loved and nobody better than she knows the arts of seduction and bewitchment.

While orgies take place in the streets of Algiers' Casbah, from prison-houses along these streets where Arab women live cloistered behind walls, their dreams, their longings of love rise up to the sky like clouds of incense! These women sold like animals, these women forced to endure polygamy, are seekers after ideals! Ask them about love, they will answer, "Love! It is a quick look, it is the embrace of arms and hands, it is a kiss! But love exists only then! Once a man is married, it is over! Over! The arms extended for an embrace drop down and cling to the body!"

Loved though they may be, Muslim women do not get attached to a polygamous husband who hurts them in their pride by sharing his heart and his favors. Their soul withdraws unto itself like flowers closing their petals as soon as they are crumpled and mutilated. These Arab women, whose delicacy no one cares to respect, are sensitive plants that tremble, rebel, and hate coarseness. More than any others in the world, these Muslim women feel deeply, having been borne by poet-mothers.

In ancient Arabia, all women were poets; the most famous was Kanza. Her renown equaled that of the illustrious Khindif who gave his name to the tribe of the BeniMondar who, under the name of Khindifides, inhabit the Hedjâz and the Nedjd. Pagan Arabia had four sages, all of them women. Their names were Sohr, Amrah, Djoumah, and Hind who in time of war made necklaces of the enemies' noses and ears. The most remarkable women of Islam were Aisha, the Prophet's favorite wife who taught poetry to children because rhythm purified the language, and Zobaidah, wife of Harun-alRashid whom she influenced in state affairs.

Muslim women are independent in a way that most French women are not. The moral subjection we call duty is unknown to them. Since their sensibility is not overstimulated by novels and religion, they do not know the bursts of passion that would drive them to sacrifice and subordinate their happiness to that of a man. They want to be happy and to find complete satisfaction for themselves.

Their lofty aspirations date from long ago, from the times of pagan society when women had the freedom to choose the life companion they liked; their aim was to enter into a marriage of "understanding;" they looked for a sympathetic husband.

Unlike women of other races who were seduced by physical beauty, they preferred moral beauty and intellectual superiority to everything else; they married the most generous, the most sensitive man. Before marrying, they put men through ordeals. 
That of the stove and perfumes ${ }^{64}$ was infallible to distinguish a man of humble birth from a man well-born.

Today's Arab woman, however crushed she might be, remembers her female ancestors and directs all her aspirations toward the highest, as testified by this proverb that heightens the vigilance of her Muslim husband-jailer: "When the wife sees the guest she no longer wants her husband." Of course the guest, nearly always European, represents for her superior education and intellectual development. What feeling other than contempt could the Muslim woman have for her jealous, lazy, distrustful master, who pockets the house key when he goes out? This is why as soon as she can escape confinement, she throws the Koran out the window and would rather give herself to twenty Frenchmen than to be bought by one Muslim husband.

\subsection{Love in the Tent}

In the past, the Mauresque did not hate the men of her race. Twelve hundred years ago in Arabia, spouses called out to each other with these sweet words: "You who belong to me!" Now that young girls - children rather - are sold by their father to a husband who could be their grandfather, love does not exist in marriage and beatings are powerless to ensure a wife's fidelity. The young wife's nature is brutalized, but one day it claims its rights and the little organ she has in her chest begins to stir, sometimes for a man she has never seen but who, when she lifted her haik, stole a glance of her murderous eyes.

"The heart is the shortest way to reach the heart," say the Arabs, so when they want to be loved, they begin by loving. The women encourage them with their flirtatious indifference, but they do not like their lovers any more than they do their husband; they are but dilettantes of infidelity. Arab women gamble their life when they betray those who love them for a jewel, or even for nothing.

In Biskra, if a woman so much as looks out the window, her husband buys one of the excellent guns made in the city and shoots her. She risks her life for a lifted corner of her veil, for a simple look. One can imagine the joy this platonic infidelity represents for the one so honored. So despite all perils, the lovers' ardor does not abate any more than the temerity of women, who are always ready to provoke the anger of the men who bought them. Arab lovers feel a violent passion for their lalla; theirs is the enthusiastic worship of knights of the Middle Ages for their valiant lady.

In the desert, Muslim women have not lost their power and play a big role in tribal wars. The most beautiful among the most beautiful women of the tribe follow the warriors, seated in rich palanquins, which are like portable boudoirs hoisted on

64 Heating several different perfumes in a portable stove was said to fend off the evil eye and let girls see the man they were going to marry. 
camels. Their songs, recitations, joyous or scornful screams inspire the combatants. After victory, the houris' participation is rewarded with a share of the loot. In pagan Arabia, some women went so far as being immodest to save their tribe: it is told that during the battle of the "Coupe des Toupets," ${ }^{65}$ the poet Hind's daughters shed their clothes and advanced completely naked among the combatants, encouraging them with their screams, "Warriors, swoop down on the enemies, bring them down, and we shall embrace you with open arms."

\subsection{The Cost of Adultery}

When the wives of polygamists are unfaithful, they are cruelly punished. The Koran is not lenient toward adultery. In chapter 24 , it prescribes one hundred lashes to both guilty parties in the presence of a crowd of believers. Verse 19 of chapter 4 is even more severe. Read and tremble: "If your wives commit the infamous action, call four witnesses; if they are in agreement against them, lock the wives up in a house until death will visit them.” Doors and windows were sealed. How many human lives have been taken by this barbarous article invented by Mohammed's jealousy?

In Oceania, adultery is atoned for with a fine of six wild pigs given by the lover to the seduced woman's husband. ${ }^{66}$ In the Sahara, the tribe's chief, who dispenses justice, puts a high price on curiosity: the man who enters a tent to look at his neighbor's wife must compensate him with ten ewes. In the Touat, adultery is punished by a severe thrashing.

In Algeria, the adulterous woman is sometimes scalped. An Arab from Douar Ouana, Afsa Essaiid, recently applied a red hot cleaver to the private parts of his cheating wife, Meyriem bent Afar. In the southern Oran region, I have seen husbands abandoned by their wives bring the unfaithful women to court in order to obtain from them five francs of damages per night spent out of their houses. Other husbands want to be compensated for any word uttered or gesture made against their wife, the property they bought. As you see, the Muslim man has a thousand small ways to get income from his wives, so it is not surprising that he marries so many of them.

65 This is the legend of the poet Hind (the nickname of the poet Chahl) and his daughters. Coupe des toupets means "cut of a tuft of hair." There was nothing more humiliating for prisoners than having a tuft of hair cut from the top of their head and then be sent back to their own people to show their defeat. (N. Perron, Les femmes arabes avant et depuis l'islamisme, Paris: 1858)

66 Obviously not a Muslim society for Muslims are forbidden to eat pork. 


\subsection{Thirteenth Century Feminists in Miliana ${ }^{67}$}

To marry is easy, to subjugate much less so. Among independent women, the Arab woman is a rebel. That is because she was not always treated as cattle.

In the times of idolatry, when Mohammed had not yet proclaimed man's superiority over his female companion, the Arab woman enjoyed the same rights and even more consideration than her husband.

Men and women, endowed with the same prodigious memory, acquired the same knowledge; they knew the same orally transmitted traditions and poems because writing and books were unknown. Emotions were expressed in verse. Women were not content to be fine talkers; they had a marvelous poetic talent which they mostly used to glorify the heroes who had died defending their tribe. Identified with poetry in the Arabs' admiration, the woman was worshipped like a kind of divinity.

Mohammed overturned her altar and made her an instrument of carnal pleasure. But this decline, this annihilation was only superficial: Islamic law could not overcome this atavism and Muslim women preserved their ancestors' love for independence in their marital prisons. Arab women raised the banner of emancipation well before European and American women did. Five hundred years ago, women from Miliana revolted against "masculinism." They were rebuked in the thirteenth century by the Arab saint Sidi-Mohamed-ben-Yusset who reproached them for "usurping the role of men, commanding instead of obeying, and finally revolting against men's rights and doing their best to abrogate them.” Bravo for our ancestors!

\subsection{A Five-Year Gestation}

Because she feels so strongly about liberty the Arab woman also feels responsible. During the whole time of gestation she is concerned with the work in progress in her body. The child she is making must be handsome! This is why, like an artist who wants to produce a work of art, she surrounds herself with creation's most charming things. Gazelles are brought to her; she gazes at them for hours every day, she licks their eyes and teeth so that the child inside her will have their white teeth and their large caressing eyes. The little one she delivers after these efforts of will is usually marvelously pretty. Is it the sun that helped the mother to mold him so well?

In Arab country, a midwife is first to arrive. When she is seen running to a tent, she is questioned, "Mra (woman), where are you going so fast?"

"I am going to divide one life into two," the woman answers, which means "I am going to deliver a woman." This village midwife, who received no other teaching than that of tradition and experience, complicates the labor of childbirth instead of easing

67 Town in Northwestern Algeria. 
it. Her barbaric practices triple the pains of women going through the ordeal of giving birth. In order to lower the high mortality of new mothers, ignorant matrons are now being replaced by qualified mid-wives, to the great joy of the natives.

Women who give birth to a son receive jewels from their husbands; those who deliver a girl are insulted, cursed, beaten! For, although girls are no longer buried alive at birth on Mount Abou-Doulamah or Mount Ben-Dalmate to be spared the misery of womanhood - as was done in the times of the poet al-Farazdaq's ${ }^{68}$ ancestor, who saved them from death by giving their parents a ransom of one female and two male camels - the birth of a girl is nonetheless considered a great misfortune for poor families.

Arab women consent to become mothers only when they are sure of wanting for nothing and being able to live with the man they married. ${ }^{69}$ After they enter their husband's dwelling, for years they turn round and round in the house or in the tent. If they find their nest sufficiently soft and warm, they will give birth to a child, rarely to several.

A poetic interpretation is given to this postponement of motherhood. The child is believed to be sleeping for a long time in his mother's womb before being born. Because of this belief, a child can be attributed to a husband five years after his death. According to Muslim law a pregnancy can last five years. "It is the maximum term of gestation indicated by God," say the legists. However, some of them dispute this duration and indicate four years as the usual term.

Even though the Koran is mute on the topic, cadis are in complete agreement

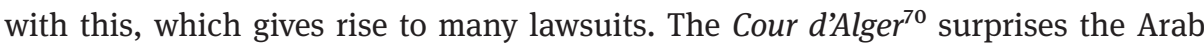
world each time it declares that the longest pregnancy does not exceed ten months. This puts an end to the demands of former brothers-in-law that a child delivered by a sister-in-law - remarried for three or four years - be considered the son of their brother deceased five years earlier. But the Cour d'Alger has also pronounced grotesque judgments, like the one that legitimized a child born more than two years after his putative father's death.

M'zabites who emigrate to work in coastal towns and leave their wives in their country recognize children born to them as their own, sometimes after being away for several years. "The besieged woman is always defeated," say the Arabs about a seduced woman. The Koran, remembering that Arabs descend from Ishmael, the natural son of Hagar and Abraham (whereas their Jewish brothers descend from Isaac, the legitimate son of Sarah and Abraham), denies the existence of illegitimate

68 Islamic poet, born c.641. died c.728 or 730 .

69 Are they initiated in M. Paul Robin's scientific method? (author's footnote)

Paul Robin (1837-1912), libertarian educator, proponent of "coeducation of the sexes." He introduced in France the neo-Malthusian principles from England and campaigned in favor of birth control for the working class in order to better their condition.

70 Highest French appeals court to which Islamic and customary cases could be raised. 
children. Babies born here and there to women during their adventurous life are recognized and raised by their mother's tribe.

The Arab woman nurses her baby; her breasts, elongated by being pulled, even sometimes drooping down to their thighs, serve to amuse as well as nourish the child.

Instead of carrying their baby in their arms as we do in France, Moroccan mothers carry them astride on their hip in a fold of their haik.

Arab mothers carry their children on their back, but only to take them from place to place; because in the house or in the tent they are put down naked on the bare earth, which forces them to struggle, to work their arms and legs in order to move. This kind of upbringing makes them vigorous and bold, that is, apt to walk early. In Algiers, the little Arab boy is supposed to bring money home as soon as he walks steadily.

"Why aren't little girls sent to the markets like little boys?" I asked one day to an older yaouled who was helping me.

"Because," he answered, they would be stolen instead of bought."

If little girls do not live outdoors like little boys, they are not inferior in intelligence: a four-year-old little girl already possesses all the seductive arts of a young woman. When a man teases her, instead of crying like a little European would do, she retorts with a woman's temerity.

One day, the chaouch ${ }^{71}$ of a provincial tribunal of the department of Algiers confided in me with great emotion, "Would you believe, the French clerk maintains that my wife and I made our children! It is neither I nor my wife! It is God! Have you ever known anyone who could make a mouth, a nose, and eyes? 'Try yourself,' I answered the clerk, 'try to make a human face!'”

"What did he answer?"

"The clerk? He burst out laughing and the entire court laughed with him."

This story alone would prove that Malthus has no disciples among naïve Muslims. Many young women, not mature enough, die in childbirth. And innumerable children of immature wives die before their sixth birthday.

In Arab countries, when a barren woman wants to have a child, she touches the tip of her finger to the lion brought by the marabouts from douar to douar, from town to town, and shown for money. This lion who can be touched with such prolific consequences is not the ferocious animal we know. It is a sweet, obedient, well behaved lion, raised in a koubba that sometimes fills North Africa with the rumors of its miracles. Every month barren women hang, on a blessed bush or an isolated tree, a piece of cloth impregnated with their menstrual blood; it is an infallible way to become fertile.

The Negro slave made a mother by her master takes the name of Ouem-el-Ouled, the child's mother, and enjoys the consideration due to legitimate wives. Her son is

71 Bailiff, attendant, guard. 
not a bastard but his half brothers' equal; like them he belongs to the tent, like them he inherits. When Negro children are six years old, their mother etches on their face with a red hot knife indelible signs which will indicate all their lives to which tribe they belong.

The Tuareg Imouchar, free men, kept the traditions of matriarchy: the child always follows the mother's blood. "It is the belly that dyes the child," says a formula of their traditional law. The son of a noble mother and a slave father is noble. ${ }^{72}$ The son of a noble father and a slave mother is a slave. It is not the chief's son who succeeds his father, but his elder sister's son. This is our Salic law ${ }^{73}$ upside down.

In Ivory Coast and in Gabon, for the Nigritians and the Tuareg of north and south, ben-oumnia, the mother's son, customary law is faithfully observed. At the death of the head of the family, his possessions are divided in two parts, the "possessions of justice" acquired by his labor and the "possessions of injustice” acquired with weapons; travelers report that the first are equally divided between all children without distinction of gender, and that all the "possessions of injustice" go to the elder sister's older son. When a conquered territory has to be distributed among tribes, it is given to the nobility's dowagers. Many Berber tribes are ben-oumnia; in Rhat, Berber law gives the management of the inheritance to women representing the former masters of the land; they alone can dispose of the houses, springs, and gardens. According to $M$. Duveyrier ${ }^{74}$ they are in no way inferior to men in management and commerce. The elder sister's son inherits the rights of command over serfs and the fees paid by travelers.

\subsection{When Prostitution is a Priesthood}

Among Arabs where women are twenty two percent fewer than men, where polygamy, which stimulates sexual appetite and encourages the monopoly of a few, causes scarcity of the female sex on the marriage market, it is not surprising that sacrifice to love is a pious deed and that prostitution is a priesthood in Algeria. The women, who follow this calling in order to please Allah, gather honors, consideration, and riches everywhere.

This tribe of love's priestesses - whose tents of a dark red color are different from those of their co-religionists, the Oulad-Sidi-Cheikh, that are grey and brown topped by a panache of ostrich feathers - occupies an immense area at the furthermost bound of the large desert between Bou-Saada and Laghouat near Djelfa. Here, men

72 Uterine nobility existed in France in the feudal period. A noble mother gave birth to a noble son even though the father was a commoner. (author's note)

73 Legal Code of the Franks.

74 M. Duveyrier lived for a long time among the Tuareg. (author's footnote)

Henri Duveyrier (1840-1892), French explorer of the Sahara. 
and women are the most perfect types of Arab beauty. The delicate men are poets and play the flute. The tribe's little girls learn to dance to the sound of that instrument when they take their first steps.

When they are nine or ten years old, when they know how to sing and dance delightfully and smoke elegantly, they emigrate in large numbers to coastal towns where they practice their profession, which consists of charming and bewitching, freely giving or selling themselves. These desert children do not accept the rules of prostitution.

The Chambaa, alerted that El-Goléa's garrison would be provided with houses of prostitution, let it be known very loudly they would rebel if women of their race were taken for this patented commerce. But they added "one can do what one wants with Negresses, they are not human beings."

The pretty almahs, the Sahara's wild virgins, delight Europeans. These houris enchant the regular visitors of cafés maures, who, in watching them dance, get a foretaste of Mohammed's paradise. The rich pour out on their hands amphorae filled with perfumes. The audience is fascinated when the charming Oulad Naiils, sparkling from head to toe with precious stones and diamonds, swathed in aromatic smoke, rise slowly one by one, as if hesitating, and enter the circle of spectators, swinging their hips in a lascivious movement. One almah follows another, offering the same irresistible, mysterious attraction, then the whole troupe parades, simulating the most provocative things, revealing under their Arab costume moving hips and bellies as distinctly as if they were bare. This belly dance ${ }^{75}$ is love without love; it causes an ecstasy of the senses of which the spectators never tire.

The music, if deafening, is stirring; next, a Negro holding iron castanets or a clarinet in his hand goes to each onlooker, and even the ragged ones give him ten to twelve duros. Poor Arabs who want to have the pleasure of pretending to be rich in front of the beautiful dancers borrow this money from Jews.

When these friendly young girls have made enough money by selling themselves to everybody, they return to their tribe and are fought over by suitors; because along with the gold, they bring a little bit of civilization in the pleats of their brocade and silk melhfa.

It is not their poverty that brought about the widespread custom of offering their daughters for a small fortune to everybody and anybody, but a belief that in so-doing they honor Allah. Convinced that women do a great deed by prostituting themselves, they encourage them in that path. According to them, renouncing this custom would attract the worst evils on their tribe. The tithe of young flesh paid to this Minotaur, ${ }^{76}$ i.e., vice, seems to them a guarantee of security. So it was in vain that Abd-El-Kader should stop them from prostituting themselves in all of Algeria: when a drought occurred, it was attributed to Allah's wrath and the old custom was reestablished.

75 The grotesque spectacle we see in France is but a horrible imitation. (author's footnote)

76 Flesh eating monster of Greek mythology. 
The noble Oulad Nails, that is, of a noble tent, act royally with their one-hour lovers; when one of them admires a rare object or one of the carpets making up the altar of love's sacrifice, they have it brought to him by their servants.

Ghadamès, more prudish than Algiers and other coastal towns, prohibits prostitution and drives prostitutes out of its walls. The kingdom of Haoussa treats them even more cruelly: in that kingdom women accused of prostitution are hanged on the public square on market day. To compensate this severity, Biskra, compared by a poet to an emerald in a golden gem, invites and adulates courtesans. They occupy one whole sector of this oasis of one hundred and fifty palm trees and they contribute to attracting winter residents at least as much as do the mehara ${ }^{77}$ races.

In the Saharan steppes, Berber marabouts called tagama (saints), who let their hair grow into long tresses so as to be noticed from afar, have a traditional industry: they offer their women for sale to foreigners. These mores can be found in tribes of Berber origin in Tripolitania.

Herodotus relates that women from Lydia indulged in prostitution. They practiced this profession until they found someone to marry. That was the way they were able to choose a husband.

77 Camel. 